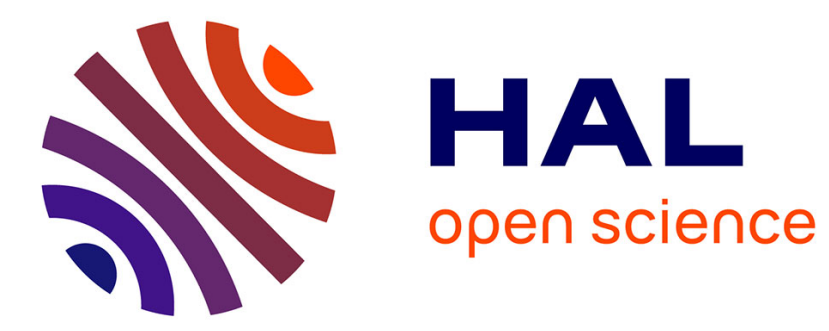

\title{
Green IT and Waste Paper in Governmental Institutions: The Proposal of the Infotercio Financial Model
}

\author{
Nilo Costa Serpa, Ivanir Costa, Rodrigo Franco Gonçalves
}

\section{- To cite this version:}

Nilo Costa Serpa, Ivanir Costa, Rodrigo Franco Gonçalves. Green IT and Waste Paper in Governmental Institutions: The Proposal of the Infotercio Financial Model. IFIP International Conference on Advances in Production Management Systems (APMS), Sep 2014, Ajaccio, France. pp.14-21, 10.1007/978-3-662-44736-9_2 . hal-01387840

\section{HAL Id: hal-01387840 \\ https://hal.inria.fr/hal-01387840}

Submitted on 26 Oct 2016

HAL is a multi-disciplinary open access archive for the deposit and dissemination of scientific research documents, whether they are published or not. The documents may come from teaching and research institutions in France or abroad, or from public or private research centers.
L'archive ouverte pluridisciplinaire HAL, est destinée au dépôt et à la diffusion de documents scientifiques de niveau recherche, publiés ou non, émanant des établissements d'enseignement et de recherche français ou étrangers, des laboratoires publics ou privés. 


\title{
Green IT and Waste Paper in Governmental Institutions: The Proposal of the Infotercio Financial Model
}

\author{
Nilo Serpa ${ }^{1}$, Ivanir Costa $^{2}$ and Rodrigo Franco Gonçalves ${ }^{1}$ \\ ${ }^{1}$ UNIP - Graduate Program in Production Engineering, Brazil \\ ${ }^{2}$ UNINOVE - Graduate Program in Production Engineering, Brazil \\ niloserpa@gmail.com, icosta11@live.com, rofranco@osite.com.br \\ http: //www .unip.br
}

\begin{abstract}
This work discusses waste paper generation in IT environments and the need to reduce the output of reports, source codes and forms in Brazilian governmental institutions to carry out a true policy of sustainability. Green IT is tackled from the premise that paper is the most bulky solid waste daily generated by informatics and the most easily controllable by people. The authors explain a green IT management model which combines finance and cleaner production so that it makes possible to rescue ethical values little remembered today at governmental level, thus keeping public treasury. Present work also explains the mathematics of the model including a preliminar simulation to clarify basic ideas.
\end{abstract}

Key words: green IT, ecological education, waste paper, infotercio, sustainability, cleaner production

\section{Introduction}

Researchers, environmentalists and professionals in computer science agree that the practice of green IT is a real need today. Green IT not only minimizes ecological impacts but favors cost containments and reduction of energy consumption [3]. In particular, management of paper is of great importance because the significative waste bulk that characterizes its use. Nevertheless, in countries like Brazil, informatics does not seem to have come to optimize processes in reducing emissions of paper (printed reports, source codes and forms). Paper generally constitutes a large portion, if not the greater, of regular office waste. Several institutions feed their giant databases and use BI (Business Intelligence) tools, but, as not satisfied with on line or batching results and not fully proficient in business intelligence, they print a cornucopia of documents, putting a great part into the drawers. More than half of these outputs end up in the trash having attended no objective requests. Worse yet, they fall into the trash with no use as drafts. Also, there is a large information redundancy in administrative proceedings, since the online reports and dashboards add up to printed replicas without 
any logical reason in a counterproductive and paradoxical process of solid waste generation.

There is a slow but growing understanding - as well as a fast increasing of information technology - that environmental problems are not separated from everyday business activity, this latter having become part of the great discussion about environmental sustainability since the nineties. Although green IT is much focused on environmental certifications and metrics on general waste emissions [6], little was writen specifically about IT's office paper disposal. Many works on general waste paper management are published ([7], [8], [14]), and, as a paticular report, the great work of Villanueva and Eder about an end-of-waste criteria and related technical requirements for waste paper to cease to be waste in the European Union [13].

This article seeks to highlight the importance of establishing institutional programs to reduce emissions of printed paper in IT environments in view of the increasing contribution of informatics to the total volume of waste paper released. In addition, it is well known that making paper from raw materials we consume $60 \%$ more energy than recycling paper by modern advanced processes, also creating $74 \%$ more air pollution and $35 \%$ more water pollution [12], a fact that justifies all efforts toward the optimization of paper consumption.

\section{Some remarks on present state}

One of the factors that contributes to the increased generation of waste paper is the lack of political commitment to the realization of certifying entities for the dissemination of systematic security by digital signature. A huge amount of paper consumed is due to the requirement of manual signatures. This feature adds to a pathetic and obsolete system of register offices which only serves to enrich socially dead loss institutions. Thus, almost all that concerns to green IT is just trick in Brazil, where the bureaucracy is the mainstay of some fortunes.

As the authors highlighted above, the literature deals with the disposal of waste paper as a whole, mainly in household trash, with less attention devoted to the waste paper from IT. The problem is that, acting in this way, institutions aimed at environmental preservation leave aside the issue of environmental education in each work sphere. The environmental and ecological information could only contribute to behavior changes in respect to the environmental preservation if we localy develop a mindset beyond the needs of the productive systems as a basis for our actions on the world, decreasing the uncertainties about the future of the Earth. To do this, communication difficulties in transferring information to other social actors need to be overcome in order to make information circulate from specialized spheres to connecting with the people affected by the environmental problems within participatory processes. Also in this field, priorities and lines of research looking at the real needs have to be defined.

In Brazil, each IT governmental area should establish a real library of recycling associated with its Committee on Information Technology (CIT) with the premise that each worker plays a key role in solid waste management, either by 
reducing consumption, or by reusing materials, or by prior separation of recyclables materials to be sent for recycling. Available documents would be videos, books, magazines, technical reports and scientific journals plus practical experience workshops of reusing materials, mainly fucusing paper recycling, although we know there are limits for this recycling [7].

\section{Environmental reasons to reduce paper consumption}

The challenges of paper recycling concern to the amount of generated pollutants and the cost of production. Indeed, in comparison to manufacturing new paper, conventional recycling technology applied to office paper leads to high costs in cover and energy, releasing more carbon dioxide due to the consumption of less renewable fuel sources. Counsell and colleagues described in details conventional and new technologies of paper recycling [1]; they studied energy demands and climate change impacts from life cycle of generic office paper. Nevertheless, prices were diminishing by economies of scale, and by decreasing the average profit margin [10]. In Europe, recycled paper on an industrial scale can cost even cheaper than virgin due to the efficiency of selective collection and more difficult access to cellulose. In Brazil, the recycled paper used to cost $40 \%$ more than virgin paper at 2001 against only $3 \%$ to $5 \%$ at 2004 [10]. Although modern paper recycling is less pollutant and expensive, the ideal measures are to break off paper use replacing it by un-printing or through the use of electronic-paper [2], cutting back demands on energy, impacts on water and emissions of climate change gases.

The only effective way to inhibit the consumption of IT office paper in governmental areas is establishing policies for release of funds associated with reduction of emissions of typical printed outputs as reports, source codes and forms. This is what the infotercio financial model proposes to do.

\section{The technical proposal and its ethical and environmental implications}

Governmental budgets for IT in Brazil are still modest, leaving managers to practically live with leftovers from other areas. This is due to the failure to recognize the IT strategic role in process optimization. On the other hand, corruption scandals succeed in a way that seems to leave no margin of solution at least in the next two generations, a sad reality that leaves a trail of unnecessary purchases and deviances that led to the scrapping of various items of infrastructure along the last two decades. Moreover, there is the fact that people completely unprepared assume by political reasons positions that require extreme technical competence and solid general education. Given the above, only a governmental system of independent IT financial management could minimize the social damage caused by this situation of ethics bankruptcy. And whenever it configures the absence of ethics it becomes impossible to talk seriously about green IT or sustainability. 


\section{$5 \quad$ The infotercio financial model}

The infotercio financial model has its origins in the early nineties, when it was discussed in some young IT sectors at Brazil the course of informatics, economics and technology in general. Serpa and Chy Hen Gin hypothesized ways to reduce the direct involvement of governmental institutions with funds annually transferred by the central government, creating mechanisms to protect public resources from the embezzlement of unethical politicians [11]. At that time, on the eve of the Gulf War, the IT certifications were still mirages; Michael Stanton honed the former Rio Network, the structural basis for the corporate web which would be established, while systems analysts and programmers seeking the best way to democratize information after so many years of authoritarian government. Ironically, while discussing the idea of the infotercio and its benefits in the boardrooms of Dataprev (Brazilian abbreviation for Data Processing Company of Social Security), President Collor, elected by the people, and his colleagues conceived an act of banditry, one of the most sinister plans that we have news, the banking confiscation in blatant disregard to the constitutional right to property.

Twenty years later, the model reappears associated with the concept of "green IT" and advances in digital technology and telecommunications. The infotercio $(\$ I N F O)$ is now a unit of green financial credit based on the principle that the greater the reduction in the emission of printed paper the higher the available credit to purchase equipment for upgrades in machinery and other IT implements including security devices and accessories as tables and chairs. There is no cash involved, just green credits computed in the organ or agency responsible for IT audits. Unlike carbon credits, infotercio credits are not matter of trade; they can not be sold, not even exchanged. The name (info $=$ "informatics" + tercio $=$ "a third part") was coined in the sense that the financial amount allocated to IT should be divided into three global groups of major processes, namely Planning, Development and Production.

The fundamental equations governing the evolution of decreasing paper emissions and growth of credits are

$$
w=w_{0} e^{-\eta t}
$$

and

$$
c=k \ln (\eta t),
$$

where $w$ is the remaining percentage of waste paper, $w_{0}$ is its initial percentage, $\eta$ is the coefficient of waste decay (depending on the internal green IT policies), $t$ is the time in years, $k$ is the financial constant (defined by government in infotercios) and $c$ is the final credit in infotercios. It is very simple to show that the relation between equations (1) and (2) is given by

$$
c=k \ln \left(-\ln \left(\frac{w}{w_{0}}\right)\right) .
$$


Exponential functions are widely used because they cover various everyday situations characterized by very fast growth or decrease, that is, situations where the growth or decrease rate is considered very significant. As everything in IT evolves rapidly, exponential functions are excellent for simulations to implementing strategic plans with regard to updates of technology and methodologies with their spendings. They contribute satisfactorily to obtain results from quantiqualitative analysis. Thus, it seems logical to use the exponential function and its inverse, the logarithmic function, to represent conjugated processes of growth and decrease.
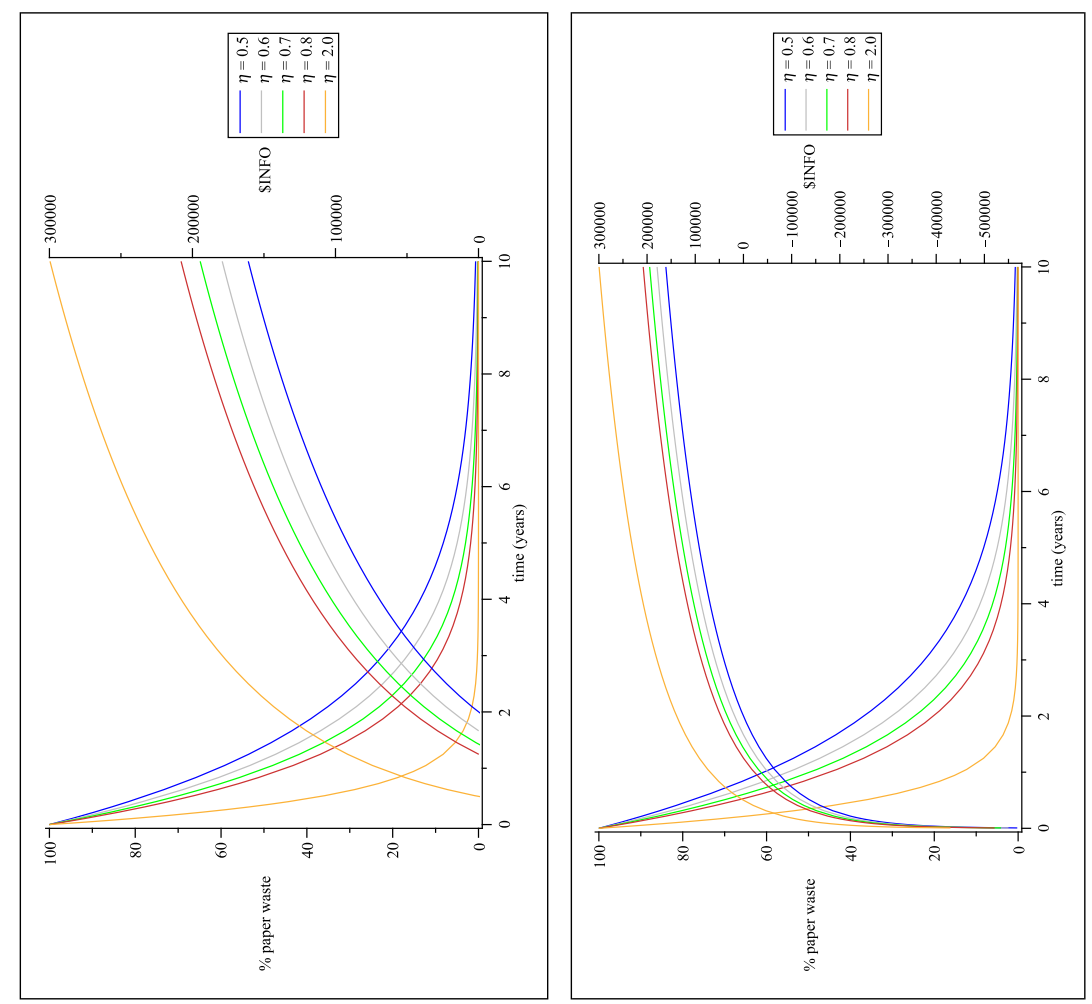

Fig. 1. a (left): the mathematical evolution of the paper waste reduction and the corresponding credits in infotercios for distinct values of the coefficient of waste decay; Fig.1. b (right): same simulation but since negative values of credits.

Fig. 1. a shows how the reduction of waste paper, year after year, from $100 \%$ of paper outputs to almost zero output, determines the credit growth in infotercios. For the simulation we consider $k=100,000$. The reader must note that credits start after a period of execution of a waste paper management plan; the more efficient the reduction, the more the bonus in credits. Institutions 
whose reduction of paper emission occur more slowly begin to credit infotercios later. If equation (2) equals to negative values, this means that institution is still not fully working to credit infotercios in face of its coefficient $\eta$ (Fig. 1. b). So, to credit infotercios, the institution must prove that it operates according to a planning for paper outputs reduction.

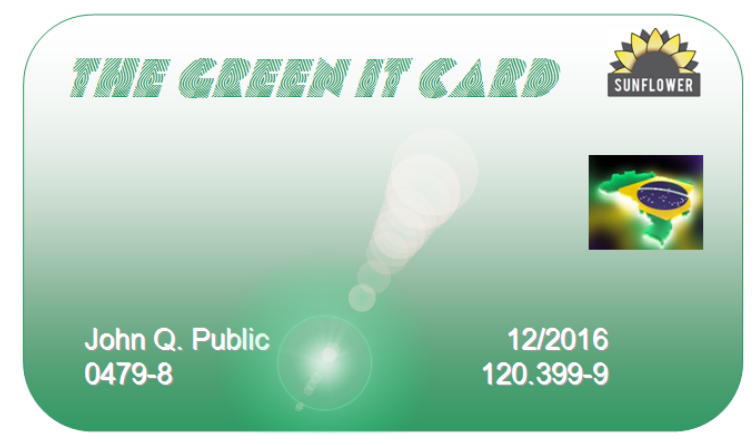

Fig. 2. First design of the Green IT Card.

Each IT manager receives the infotercio green IT card as designed in Fig. 2 , with which they can monitor the available amount of credits and release the amount required to purchase a given service or equipment when approved by the Federation General Comptroller (FGC). The Sunflower picture is a sponsor trade mark of Gauge-F Enterprises, a company that provides an unpaid program of environmental education for children. The unit value of the infotercio is assigned by the government, according to public policies of economy and sustainability. Each governmental institution forwards to the FGC its Term of Reference on the acquisition of some equipment or IT service. Faced with availability in infotercios, the term is referred to legal analysis and, once approved, it will be initialized the bidding process based on technology and price. Although each institution manages its bidding processes, only the FGC will approve or not the end result of the bidding and the liberation of funds, making direct payments and auditing the performance of the contracts. No money is transferred to the requesting institutions. Annual credits are available along with the budgets of each ministerial portfolio. Receiving of credits is permanent and works as an independent annual budget for IT, ensuring technological autonomy for each institution and environmental sustainability.

\section{Discussion}

One immediate advantage of this model is to reduce the risk of malpractice with public resources. Furthermore, we recover the importance of technical criteria 
in choosing the most advantageous solution for society. Also, the institutional potential to generate infotercios is proportional to the ecological enlightenment of workers in IT and to the execution efficiency of the IT strategic planning with regard to environmental issues. Obviously, in practice the reduction process is asymptotic, since it would be difficult to completely abolish IT's office paper. Assuming that the institution shall stabilize at a certain level of containment of paper emissions, it shall remain getting the same value in infotercios. Lastly, deadlines must be made less conservatives, something like 4-6 years for the entire cycle of reductions considering internal bureaucracy. Although there is not the case to detail the subject for reasons of strict constraint, it is interesting to consider the future implementation of a study focusing the return on investment associated with the infotercio financial model. A promising analysis of return on investment can be found in the explanatory work of Williams and Parker directed mainly to the discussion of the decrease in volumes generated by industrial activities [15]. This work shows how it is possible to calculate in monetary terms the noncash and external costs and benefits coming from a project, converting to dollars the relevant social and environmental impacts of that project. This process of conversion, operating at the intersection of economics and sustainability, is referred to as the Sustainable Return on Investment (SROI).

Another important aspect is that the model gives rise to the need for widespread knowledge about the ways of consuming paper in order to promote a better quality material for recycling, since successful recycling requires paper free from filth, such as grease, food or glue, which make difficult the recycling. Also, wood fibers may be recycled five, six, maximum of seven times before they become too small to be recycled into renewed good paper. But not only this; much of the waste produced in underdeveloped countries is incinerated, releasing in the air a wide range of substances harmful to health. A considerable portion of this waste is constituted by various kinds of paper. Severe health issues like cancer, adverse reproductive development and suppression of the immune system are caused by dioxin, a very toxic chemical release present in smoke from burning waste paper and other trashes ([4], [9]). Thus, the less paper waste is generated by IT, the lower the risk of dioxin emissions, and the more the organization and preparation of waste paper under policies of reuse, the greater the possibility of recycling.

\section{Conclusion}

Obviously, green IT is not limited to the issue of waste paper generation from unnecessary forms and reports, but, from the point of view of economy and disposal procedures within the reach of technical people in their day-to-day role, waste paper stands out as the most striking solid polluter in terms of spoilage volume. This article presented the so-called infotercio financial model to centralize the management of governmental IT resources in Brazil into the scope of cleaner production and sustainability as an alternative for the current administrative patterns still lacking in ecological education. Programs of this type suggest a 
certification system for both managers and institutions, ensuring quality and environmental responsibility. Such a system will be the subject of another study in the light of the ISO 14000 family and its Brazilian derivatives. Present article also starts a wide debate on green IT, motivating experiments that can show the entire feasibility of the model.

\section{References}

1. Counsell, T., Allwood, J.: Desktop Paper Recycling: A Survey of Novel Technologies that Might Recycle Office Paper Within the Office. Journal of Materials Processing Technology 173, 111-123 (2006)

2. Counsell, T., Allwood, J.: Reducing Climate Change Gas Emissions by Cutting out Stages in the Life Cycle of Office Paper. Resources, Conservation and Recycling 49, 340-352 (2007)

3. Cristóvão, A., Costa, I., Neto, A.P.A., Cao Ji Can: A Case Study on the Benefits that Virtualization Provides the IT and its Positive Impact on the Environment. In: APMS 2012 International Conference Advances in Production Management Systems, The Pennsylvania State University, Pennsylvania (2012)

4. EPA - United States Environmental Protection Agency: Improving Air Quality in Your Community, http://www.epa.gov/air/community/details/barrelburn_addl_ info.html

5. DEC - Department of Environment and Conservation: Reducing Paper Waste at Work, http://www.livingthing.net.au/rc/guides/05638_Paperwaste.pdf

6. Jenkin, T.A., Webster, J., McShane, L.: An Agenda for 'Green' Information Technology and Systems Research. Information and Organization 21, 17-40 (2011)

7. Levlin, J.: The Limits of Paper Recycling, http://www.cost-e48.net

8. Merrild, H., Damgaard, A., Christensen, T.H.: Life Cycle Assessment of Waste Paper Management: The Importance of Technology Data and System Boundaries in Assessing Recycling and Incineration. Resources, Conservation and Recycling $52,1391-1398$ (2008)

9. MH - Ministry of Health: Technical Guidelines for Preparation of the Program of Health Education and Social Mobilization (HESMP); Implementation, Expansion or Improvement of Systems of Treatment and Final Disposal of Solid Waste for the Control of Diseases. ASCOM/FUNASA, Brasilia, Brazil (2004)

10. Pinto-Coelho, R.: Reciclagem e Desenvolvimento Sustentável no Brasil. Recóleo, Belo Horizonte, Brasil (2009)

11. Serpa, N., Chy Hen Gin, R.: Talks on the Way You Pay for Nothing. Dataprev, Rio de Janeiro, Brasil (1990)

12. Siegler, K., Gaughan, B.: A Practical Approach to Green IT, http://www.itmanagement.com/land/green-it-webinar/?tfso=2058

13. Villanueva, A., Eder, P.: End-of-Waste Criteria for Waste Paper: Technical Proposals. Publications Office of the European Union, Luxembourg (2011)

14. Villanueva, A., Wenzel, H.: Paperwaste-Recycling, Incineration or Landfilling? A Review of Existing Life Cycle Assessments. Waste Management 27, 29-46 (2007)

15. Williams, J., Parker, J.: Measuring the sustainable return on investment (SROI) of waste to energy. In: Proceedings of the 18th Annual North American Waste-toEnergy Conference - NAWTEC, Orlando (2010) 